\title{
Development and Evaluation of Value-Added Biscuits of an Under-Utilised Bitter Melon Plant
}

\author{
*Jimah, A. Odion-Owase, E. Suleiman, M. \\ Department of Food Technology, Auchi Polytechnic Auchi
}

\begin{abstract}
Bitter melon plant is often used for some medicinal purposes in traditional medicine but its value added food products was investigated. Wheat biscuits were made for diabetic and health conscious individuals by incorporation of bitter melon extract at different levels such as $0 \%, 3 \%$ and $5 \%$ as sample A (control), B and C respectively. Sensory properties of the bitter melon biscuits were ranked above acceptable range by panel of judges; however, the biscuit with $100 \%$ wheat was far ranked highest in colour, texture, taste, flavour, and general acceptability. There was significance difference $(\mathrm{p} \leq 0.05)$ among the three samples. The acceptability of sample A was 8.70 while sample B and C were 7.10 and 6.40 . The proximate composition showed that there was significnt difference $(\mathrm{p} \leq 0.05)$ among the three samples in all the parameters analysed. The incorporation of bitter melon powder into the biscuits increased the ash content from 1.21 to $1.42 \%$, fat content from 1.61 to $1.72 \%$, protein from 2.37 to $2.49 \%$. On the other hand, the crude fibre and carbohydrate were decreased significantly. This could be that the bitter melon biscuit reduced the high carbohydrate content to a low content from $87.16 \%$ to $84.17 \%$. The phytochemical content increased as more bitter melon powder was incorporated into the biscuits and there was significant difference $(\mathrm{P} \leq 0.05)$ among the samples. There was increased in phytate from $1.28 \%$ to $1.64 \%$, tannin was 1.30 to $1.44 \%$, oxalate was 1.10 to $1.33 \%$, saponin was 0.41 to $0.48 \%$ and alkaloid was 0.21 to $0.28 \%$ respectively. Thus, the products developed had higher ash, fat, protein and all the phytochemicals and sample B also had good colour, flavour and palatability and could still benefit diabetic, obese and health conscious people.
\end{abstract}

Keywords: bitter melon, biscuit, proximate composition, phytochemicals, sensory evaluation, diabetes

DOI: $10.7176 / \mathrm{FSQM} / 105-06$

Publication date: February $28^{\text {th }} 2021$

\section{Introduction}

Bitter melon/gourd (Momordica charantia) is a tropical and subtropical vine of the family cucurbitaceae widely grown in India, south Asia, China, Africa and the Caribbean. Bitter melon as fondly called has been implicated experimentally to achieve a positive sugar regulatory effect by suppressing the neural response to sweet taste stimuli and also keep the body functions operating normally (Sofowora, 2006). The Yoruba people of Nigeria popularly call it ejinrin. Igbo-kakayi and Hausa-gàraàfúnii (Egbon et al., 2015). Bitter melon is very bitter in taste and dark green in colour; hence it is not consumed widely for the table purpose. The characteristic bitter taste of bitter gourd is due to the bitter principle 'Momordicin'. The excellent nutritive and therapeutic value of this fruit offers a great potential for processing of quality products (Deepa, 2015). The fruits of bitter melon are very much consumed as fresh and as dried vegetable for curries, bakery products, pickled or stuffed products of meat. It is also used for the preparation of several dishes. It can be fried, deep-fried, boiled, pickled, juiced, and dried to drink as tea (Myojin et al., 2008).

To study its food value, Din et al. (2011) developed beverage from bitter gourd for diabetic and health conscious individuals by incorporation of bitter gourd extract at different levels such as 5 percent, 10 percent, 15 percent and 20 percent and were investigated. Sensory properties of the dietetic ready-to-serve beverage were ranked above acceptable range by a panel of judges during storage. Results showed that bitter gourd beverage with 15.0 percent extract had good flavour, palatability and storage stability and could benefit diabetic, obese and health conscious people (Deepa, 2015). Recently, several phytochemicals with the health benefits of bitter gourd have been isolated and studied (Murakami et al., 2001). Charantins, a mixture of steroidal saponins that are abundant in the fruit of bitter gourd, have been proposed to contribute to the hypoglycemic and antihyperglycemic activity of bitter gourd (Harinantenaina et al., 2006). Other uses of the plant include is to expel intestinal gas, for tumours, wound treatment, rheumatism, malaria, vaginal discharge (Sofowora, 2006). A tea preparation from the leaf is used for diabetes in Nigeria, Ghana and India peninsula (Egbon et al, 2015) The young fruits and shoots are reported to serve as supplementary or emergency food in some part of West Africa, and it is a popular food throughout southern Asia, India, China, Pakistan, Bangladesh, Vietnam, Philippines, Nepal, and Trinidad and Tobago (Bagchi, 2005).

Biscuits are one of the popular cereal foods; apart from bread, consumed in Nigeria. Biscuits are confectionery dried to very low moisture content. They are small thin crisp cake made from unleavened dough and are important baked product in human diet and are usually eaten with tea (Olatidoye et al, 2014). They are ready-to-eat, convenient and inexpensive food products, containing digestive and dietary principles of vital 
importance. They are nutritive snacks produced from unpalatable dough that is transformed into appetizing product through the application of heat in oven (Olatidoye et al, 2014). Biscuit has been suggested as a better use of composite flour than bread due to their ready-to-eat (RTE) form, wide consumption, relatively long shelf life and good eating quality (Yelmi, 2014).

In spite of having amazing health benefits, bitter gourd is not consumed. Very little attention has been given for the development of bitter gourd products in Nigeria and the literature available on this aspect is meagre (Egbon and Jimah, 2015). Therefore, the prevailing situation is provoking us to develop value added biscuits incorporated with bitter melon powder and evaluate their sensory properties, proximate composition, as well as the biologically important phytochemicals.

\section{Methods}

\section{Collection of Plant Materials}

Fresh fruits of the plant were harvested between June and July, 2019, in Auchi, Edo State, Nigeria. They were identified and authenticated by Department of Botany, Ambrose Alli University Ekpoma, and Nigeria. The plant materials were sorted out to eliminate all extraneous materials. The samples were washed with the deionised water to remove dust particles.

\section{Processing of Powder Samples}

Blanching: The sample was blanched in hot water with 5 percent sodium chloride at $100{ }^{\circ} \mathrm{C}$ for three minutes to remove bitterness and maintaining the firmness of the bitter gourd slices.

Dehydration: Bitter gourd sample was drained, cut into small pieces and dried in hot air oven at $60^{\circ} \mathrm{C}$ for $8-10$ hours. The dehydrated bitter gourd was ground to fine powder, passed through a $60 \mathrm{~mm}$ mesh sieve. The sliced fruits were dried in a hot air oven (SD 93114624, Gallenkamp, United Kingdom) (Odetola and Akojenu, 2000).

Grinding: After drying, the plant materials were pulverised to powder using an electric blender. $100 \mathrm{~g}$ of the powdered sample each were stored in airtight containers and kept under normal room temperature until required.

\section{Formulation of bitter melon biscuits}

The ingredients and quantity ( $\mathrm{g}$ or \%) used in the baking are wheat flour $100 \mathrm{~g}$, bitter gourd powder 0,3 and $5 \mathrm{~g}$ (representing sample A, B and $\mathrm{C}$ respectively). Other additives are baking powder $2 \mathrm{~g}$ sugar $6 \mathrm{~g}$ salt $5 \mathrm{~g}$ and fat $5 \mathrm{~g}$

\section{Preparation of bitter melon biscuits}

Wheat flour, baking powder and bitter gourd powder were sieved twice. The creaming of fat was done with the sugar. Then, prepared flour mixed with creamed fat and sugar into dough. The dough was rolled shaped into the biscuit using biscuit cutter. The biscuits were baked at $160^{\circ} \mathrm{C}$ for 10 minutes. The biscuit were then removed from the oven, cooled, packaged and stored

Wheat flour sieved and incorporation of bitter gourd powder at different levels

$$
\begin{aligned}
& \text { Baking powdey, sieving twice } \\
& \text { Mixing with creathed fat and sugar } \\
& \text { Final mixing fo dough making } \\
& \text { Spreading (uni orm thickness) } \\
& \text { Sizing and shaping } \\
& \text { Baking at } 160 \text { for 10minutes } \\
& \text { Cooling, Packng and Storing }
\end{aligned}
$$

Figure 1: Flow chart of preparation of biscuit

\section{Sensory evaluation of bitter melon biscuits}

Biscuits developed by incorporating various quantity of bitter melon powder were coded as sample A, B and C and subjected to sensory evaluation by ten panel member of Department of Food Technology, Auchi Polytechnic Auchi. A nine point Hedonic Scale was adopted for the evaluation by 10 semi trained panelists. The panelists were asked to rate each sensory attribute using the control products sample A, as the basis for evaluation. The products were evaluated for appearance, texture, colour, aroma, taste and overall acceptability on 9-point hedonic scale ranging from 9 (like extremely) and 1 (dislike extremely).

\section{Proximate Analysis bitter melon biscuits}

The proximate analysis was carried out according to the procedure of Association of Official Analytical Chemist (AOAC, 2012) Moisture content (AOAC 934.01) was determined by evaporation by heat using dry oven at $100^{\circ} \mathrm{C}$, Crude Fat Content (AOAC 920.39) was determined using solvent extraction (soxhlet) method, Crude Protein Content (AOAC 955.04) by Kjeldahl method, Crude Fibre Content (AOAC 962.09) by Gravimetric 
method and carbohydrate by difference according to Ihekoronye and Ngoddy, 1985.

\section{Phytochemical Analysis bitter melon biscuits}

The analysis for phytate, tannin, oxalate, saponins, and alkaloids were carried out according to standard methods (Sofowara, 2006).

\section{Statistical Analysis}

All the data obtained were subjected to analysis of variance. Simple means were reported using Duncan's multiple Range test $(\mathrm{P} \leq 0.05)$. Results were then presented as mean \pm standard deviation $(\mathrm{SD})$. This was done with Statistical Packages for Social Sciences (SPSS version 20.0).

\section{Results}

Table 1: Sensory Evaluation of Bitter melon biscuits

\begin{tabular}{llllll}
\hline \multicolumn{5}{c}{ Parameter } \\
\hline Sample & Colour & Texture & Taste & Flavour & General \\
& & & & Acceptability \\
\hline A & $8.50^{\mathrm{a}} \pm 0.85$ & $8.60^{\mathrm{a}} \pm 0.52$ & $8.40^{\mathrm{a}} \pm 0.84$ & $8.70^{\mathrm{a}} \pm 0.48$ & $8.70^{\mathrm{a}} \pm 0.67$ \\
B & $7.50^{\mathrm{a}} \pm 0.85$ & $7.60^{\mathrm{b}} \pm 0.84$ & $7.20^{\mathrm{b}} \pm 1.40$ & $7.00^{\mathrm{b}} \pm 1.49$ & $7.10^{\mathrm{b} \pm 1.29}$ \\
$\mathrm{C}$ & $5.90^{\mathrm{b}} \pm 1.60$ & $6.30^{\mathrm{b}} \pm 1.34$ & $6.90^{\mathrm{c}} \pm 1.10$ & $6.50^{\mathrm{b}} \pm 2.07$ & $6.40^{\mathrm{b}} \pm 1.65$ \\
\hline
\end{tabular}

*Values with the same superscript in the same column are not significantly different $(\mathrm{P} \leq 0.05)$

*Results are presented as mean \pm Standard Deviation

Table 2: Proximate composition of Bitter melon biscuits

\begin{tabular}{llll}
\hline & \multicolumn{3}{c}{ Sample } \\
\cline { 2 - 4 } Parameters (\%) & $\mathbf{A}$ & $\mathbf{B}$ & $\mathbf{C}$ \\
\hline Moisture & $6.21^{\mathrm{b}} \pm 0.02$ & $6.05^{\mathrm{c}} \pm 0.02$ & $6.31^{\mathrm{a}} \pm 0.02$ \\
Ash & $1.21^{\mathrm{c}} \pm 0.01$ & $1.31^{\mathrm{b}} \pm 0.01$ & $1.42^{\mathrm{a}} \pm 0.01$ \\
Crude Fibre & $1.73^{\mathrm{a}} \pm 0.01$ & $1.52^{\mathrm{b}} \pm 0.01$ & $1.36^{\mathrm{c}} \pm 0.12$ \\
Fat & $1.61^{\mathrm{c}} \pm 0.02$ & $1.68^{\mathrm{b}} \pm 0.01$ & $1.72^{\mathrm{a}} \pm 0.02$ \\
Protein & $2.37^{\mathrm{c}} \pm 0.02$ & $2.42^{\mathrm{b}} \pm 0.01$ & $2.49^{\mathrm{a}} \pm 0.01$ \\
Carbohydrate & $87.16^{\mathrm{a}} \pm 0.03$ & $86.31^{\mathrm{b}} \pm 0.01$ & $84.17^{\mathrm{c}} \pm 0.02$
\end{tabular}

*Values with the same superscript in the same column are not significantly different $(\mathrm{P} \leq 0.05)$

*Results are presented as mean \pm Standard Deviation

Table 3: Phytochemical Constituent of Bitter melon Biscuits

\begin{tabular}{lccc}
\hline & \multicolumn{3}{c}{ Sample } \\
\cline { 2 - 4 } Parameters (\%) & A & B & C \\
\cline { 2 - 4 } Phytate & $1.28^{\mathrm{c}} \pm 0.02$ & $1.31^{\mathrm{b}} \pm 0.01$ & $1.64^{\mathrm{a}} \pm 0.01$ \\
Tannin & $1.30^{\mathrm{c}} \pm 0.01$ & $1.37^{\mathrm{b}} \pm 0.01$ & $1.44^{\mathrm{a}} \pm 0.03$ \\
Oxalate & $1.10^{\mathrm{c}} \pm 0.01$ & $1.21^{\mathrm{b}} \pm 0.01$ & $1.33^{\mathrm{a}} \pm 0.03$ \\
Saponin & $0.41^{\mathrm{c}} \pm 0.01$ & $0.46^{\mathrm{b}} \pm 0.01$ & $0.48^{\mathrm{a}} \pm 0.01$ \\
Alkaloid & $0.21^{\mathrm{c}} \pm 0.02$ & $0.26^{\mathrm{b}} \pm 0.01$ & $0.28^{\mathrm{a}} \pm 0.01$ \\
\hline
\end{tabular}

*Values with the same superscript in the same column are not significantly different $(\mathrm{P} \leq 0.05)$

*Results are presented as mean \pm Standard Deviation

*KEY:

Sample A $=100 \%$ wheat flour biscuit

Sample B $=100 \%$ wheat flour $+3 \mathrm{~g}$ Bitter melon powder

Sample $\mathrm{C}=100 \%$ wheat flour $+5 \mathrm{~g}$ Bitter melon powder

\section{Discussion}

Table 1 showed the Sensory evaluation of biscuit that were prepared by incorporating bitter melon powder at different proportions of 0,3 and 5percent. Control biscuits (sample A) were prepared without the addition of bitter melon powder. The control biscuits scored higher values for overall acceptability. Among bitter melon biscuit, the 3 percent incorporated bitter melon was found to be best with scores of overall acceptability (7.10), 
least scores were observed for biscuit prepared by 5 percent incorporating bitter gourd powder with scores for overall acceptability (6.40) as shown in table 1. There was a significant difference among all samples for all sensory attributes but are in the acceptable level. As the incorporation of powder increases there was decrease in overall acceptability due to their bitter taste.

Table 2 showed the proximate composition of the control wheat biscuit, 3\% and 5\% incorporated bitter melon biscuits. There was significant difference $(\mathrm{p} \leq 0.05)$ among the three samples in all the parameters analysed. The incorporation of bitter melon powder into the biscuits increased ash content from 1.21 to $1.42 \%$, increased the fat content from 1.61 to $1.72 \%$, increased the protein from 2.37 to $2.49 \%$ with significant difference ( $\mathrm{p} \leq 0.05$ ) among the samples. On the other hand the crude fibre and carbohydrate were decreased significantly. This showed that the bitter melon has reduced sugar content of carbohydrate from $87.16 \%$ for wheat biscuit to $84.17 \%$. This further revealed that bitter melon biscuit will be good for diabetic patients. The significant increased in protein and fat content on the biscuits incorporated with bitter melon will help build the body and provide energy.

Table 3 showed the phytochemicals with significant difference $(\mathrm{P} \leq 0.05)$ among the samples for $100 \%$ wheat biscuit and the bitter melon incorporated samples. As more bitter melon was incorporated into the biscuits, there was significant increased in the value of all the phytochemical. There was increased in the value of phytate from $1.28 \%$ to $1.64 \%$, tannin 1.30 to $1.44 \%$, oxalate 1.10 to $1.33 \%$, saponin 0.41 to $0.48 \%$ and alkaloid 0.21 to $0.28 \%$ respectively. These observations therefore support the medicinal use of the leaves in curing some ailments. Bakare et al, 2010 reported that tannins are known to react with proteins to provide the typical tanning effect which is important for the treatment of inflamed or ulcerated tissues. The presence of saponins supports the fact that the biscuits have bitter taste from steroidal saponins called charantin, which act like peptides and certain alkaloids that effectively control sugar level in blood and show marked physiological effects when administered to animals. The presence of these secondary metabolites in the bitter melon biscuits showed that they can benefit diabetic, obese and health conscious people

\section{Conclusion}

The result obtained in this study showed that the value added food products developed from bitter melon contains appreciable amount of nutrients and Phytochemicals. These will be good for processing food products which can serve as successful dietetic products for subjects with disorders viz. obesity, diabetes, cardiovascular problems and general health problems.

\section{Recommendations}

i Researches should be carried out to reveal more chemical constituents of the food

ii Further studies on the food value of the bitter melon snacks should be undertaken

iii Based on the sugar regulating effect of the bitter melon, it is highly recommended for diabetic patients

iv Traditional medicine practitioners should be given enlightenment on the use of bitter melon

$\mathrm{v}$ Bitterness component in the bitter gourd i.e. "Momordicin" need to be analyzed

\section{Acknowledgement}

The authors are thankful to TETfund for providing this Institution Based Research (IBR) grant to facilitating this research. This indeed has given us the opportunity to contribute our quota to the nation building in term of food production and development. Thank you so much.

\section{References}

AOAC (2000). Official methods of analysis. Association of Official Analytical Chemists, 22 ${ }^{\text {nd }}$ Edition, Washington D.C, pp. 3560.

Bagchi, I. (2005). "Food for thought: Green 'karela' for Red China". Times of India

Bakare, R. I, Magbagbeola, O. A., Akinwande, A. I. and Okunowo O. W (2010) Nutritional and chemical evaluation of Momordica Charantia, Journal of Medicinal Plants Resources 4(21): 2189-2193,

Deepa, J. (2015). Development of Value Added Products from Bitter Gourd. MSc Thesis. University of Agricultural Sciences. Bengaluru.

Din, A., Bukhari, S. A. H., Salam, A. And Ishfaq, B., (2011), Development of Functional and Dietetic Beverage from Bitter Gourd. Internet Journal of Food Safety.13:355-360.

Egbon, E. E, Jimah, A and Okojie. V. U. (2015). Proximate And Essential Nutrient Compositions Of Momordica Charantia Plant. Cancer Biology. 5(3) 29 - 33

Egbon, E E and Jimah, A (2015) Phytochemical Evaluation Of Selected Nigerian Medicinal Plants. Cancer Biology. 5(3) 35 - 37

Harinantenaina L, Tanaka M, Takaoka S, Oda M, Mogami O, Uchida M, Asakawa Y. (2006). Momordica charantia constituents and antidiabetic screening of the isolated major compounds. Chemical and 
Pharmaceutical Bulletin 54: 1017-1021.

Ihekoronye, A. J. and Ngoddy. P. O. (1985). Integrated Food Science and Technology for the Tropics. $1^{\text {st }}$ Edition, Macmillan Publishers Ltd

Murakami T, Emoto A, Matsuda H, Yoshikawa M. (2001). Medicinal foodstuffs. Chemical and Pharmaceutical Bulletin 49: 54-63.

Myojin, H., Singh, T. K. and Alkesh, (2008). Studies on processing and development from bottle gourd. Indian Journal of Nutrition .Dietetics .45: 371-378.

Odetola, A. A., Akojenu, S. M. (2000). Antidiarrhoeal and gastrointestinal potentials of the aqueous extract of Phyllanthus amarus (Euphorabiaceae). African Journal of Medical Sciences. 29: 119-122.

Olatidoye, O. P., Alabi, O. A. and Sobowale, S. S. (2014). Physiochemical, sensory and Nutritional Properties of Biscuit Produced from Cassava-soybean-coconut composite flour. Book of Extended Abstracts of the $38^{\text {th }}$ NIFST Conference and General meeting, Lagos. pp. 80, 81

Sofowora, A. (2006). Medicinal Plants and Traditional Medicine in Africa. Ibadan, $2^{\text {nd }}$ Edition, Spectrum Books Ltd., Nigeria. pp. 151-153, 209-214

Yelmi, B. M. (2014). Production and nutritional assessment of biscuits from blend of wheat, millet and selected legume flours. An MSc dissertation University of Maiduguri. pp. 1 - 3 